COMMENTARY ON COVID-19 AND THE Food SYSTEM

\title{
Food systems disruptions: Turning a threat into an opportunity for local food systems
}

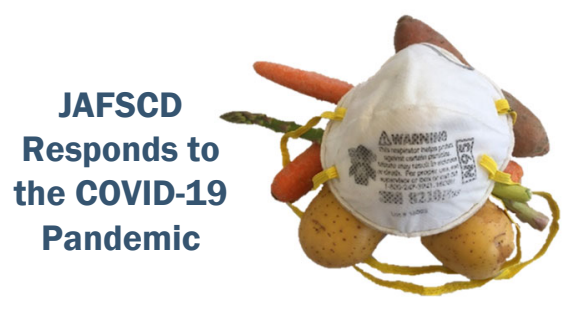

Jane Kolodinsky a*

University of Vermont

Marilyn Sitaker ${ }^{b}$

The Evergreen State College

Lisa Chase ${ }^{c}$

University of Vermont Extension

\author{
Diane Smith ${ }^{\mathrm{d}}$ \\ Washington State University Extension
}

Weiwei Wang ${ }^{\mathrm{e}}$

University of Vermont

Copyright (C) 2020 by the Authors. Published by the Lyson Center for Civic Agriculture and Food Systems. Open access under CC-BY license.

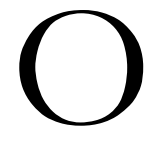

ur food system has been disrupted. Shopping at a grocery store during the COVID-19 pandemic is not a pleasant experience, and, for some of the most vulnerable, it can be outright dangerous. It may become worse. How long will supply chain disruptions continue and what are upcoming challenges? From illness in the fields where agricultural workers pick our food and the closing of food processing facilities to the threat that trucking lanes may be shut down, the possibilities seem real right now. According to Zippy Duvall, president of the American Farm Bureau Federation,

\footnotetext{
a* Jane Kolodinsky, Ph.D., Department of Community Development and Applied Economics, University of Vermont, Burlington, VT, USA; Jane.Kolodinsky@uvm.edu

${ }^{\mathrm{b}}$ Marilyn Sitaker, MPH, Ecological Agriculture and Food Systems, Evergreen State College, Olympia, Washington, USA.

c Lisa Chase, Ph.D., University of Vermont Extension, Brattleboro, VT, USA.

d Diane Smith, M.A., RD, Washington State University Extension, Burlington, WA, USA.

e Weiwei Wang, Center for Rural Studies, University of Vermont, Burlington, VT, USA.
}

There's a lot of things that happen to the food before it gets to the consumer, whether it be in processing or transportation. If this thing was to get worse, what problems come along with that? None of us really know. (Shroetenborer, 2020, para. 4)

How will we feed ourselves?

There has been a spike in interest in local food, and corresponding growth in the number of local 
food options (Low et al., 2015; U.S. Department of Agriculture [USDA], 2017). But, despite a growing demand for fresh, local food via community supported agriculture (CSA) shares, farmers markets, farm stands, and, yes, mail order, few Americans participate in the local food system. In Vermont, often looked to as a leader in local food systems, local food purchasing increased to $6.9 \%$ in 2014 (US $\$ 189$ million) compared to 5\% in 2010 (Carter, 2017). Nationally, the USDA has reported that farms with local food sales represent $7.8 \%$ of U.S. farms, and local food sales account for an estimated $1.5 \%$ of the value of U.S. agricultural production (Low et al., 2015). But those figures include sales to institutions such as schools and restaurants, both functionally out of business due to the COVID-19 pandemic.

The pandemic, which is threatening not only human health but also the health of businesses, including farms large and small, has led, at least anecdotally, to both a business model change by farmers and a behavioral change by consumers. With restaurants and schools closed, American consumers are clearing grocery shelves faster than our industrial food system can keep up (Johnson, 2020). People are eating at home, which means more food in homes. Reports from around the country indicate that consumers are changing not only where they eat, but where they buy their food. For some farmers, this is a bright spot in the agricultural industry, even as we see some farms struggling (Yaffey-Bellany \& Corkery, 2020). If changes in buying and eating habits persist beyond the pandemic, we may see hope for the expansion of local food systems. Indeed, a larger change in the way most Americans buy food has been needed to move local and regional food systems forward.

Three years ago, our team from the University of Vermont, The Evergreen State College, Washington State University, and University of California Cooperative Extension were awarded a grant aimed at getting fresh local foods to people who are unable or unwilling to participate in the local fresh food system. Whether they found it unaffordable, that those markets "weren't their people," or more inconvenient, we hypothesized that there must be a better way to provide access to fresh, local food to consumers, while supporting farmers and small local retailers. The Farm Fresh Food Box (F3B) project was born.

It had been several years in the making. Why not take the best of a CSA and make it "not a mandatory subscription"? What if farmers without enough to wholesale but an abundance of produce had a new place to sell it? What if this produce were available at local grocers in the community where consumers already shopped? We knew there would be some challenges. How do you develop farmer/retailer pairings that worked? Would consumers buy a box of produce at a reasonable price when they could not choose the exact contents?

Our team of researchers, Cooperative Extension educators, and students have provided solid support for the concept (Chase et al., 2017; Chase et al., 2019; Kolodinsky, 2017; Kolodinsky et al., 2019; Sitaker et al., 2017; Sitaker et al., 2018; Sitaker, McGuirt, Wang, Kolodinsky, \& Seguin, 2019; Smith et al., 2017; Smith, Greco, Van Soelen Kim, Sitaker, \& Kolodinsky, 2018; Smith, Wang, Chase, Estrin, \& Van Soelen Kim, 2019; Van Soelen Kim et al., 2019). The model can work. Farmers earned a bit more income and did not have to staff a farmers market or be around for consumers to come to their farm. Small grocery and convenience store retailers potentially can sell more of other goods when consumers pick up their Farm Fresh Food Box. And, consumers were happy with the quality of the produce in the box.

While the consumers who purchased Farm Fresh Food Boxes were very pleased, this innovation in getting more fresh food to more people did not seem to take off. The number of boxes sold during the pilot was relatively small: 800 over two years in seven locations in three states. While Farm Fresh Food Boxes were less expensive than farmers market produce, the box came without choice and had to be preordered. These barriers seem to be higher than the benefits of obtaining fresh produce and supporting the local economy. If consumers do not see a relative advantage, they will not buy. 
But our world has become unhinged. Going to a supermarket and buying the produce from open shelves is no longer the convenient, "cheap" alternative. Local farms have come to the rescue in all three of the states where our project was implemented (Crampton, 2020; Northwest Harvest, 2020; Schmidt et al., 2020; Vermont Land Trust, 2020). CSA shares have surged, and some farm stands and farmers markets report skyrocketing sales (Ricker \& Kardas-Nelson, 2020). National Farm to School partners are incorporating local food into emergency feeding programs, especially when existing relationships between schools and producers are already strong (Harris \& Stephens, 2020).

When the COVID-19 pandemic is over and citizens return to a new normal, maybe that normal will include purchasing already boxed produce from trusted, local farmers sold through local grocers. Not only might people have access to fresher, local food, they will also be supporting their local farmers and contributing to the resilience of our food system. Even some proponents of industrial food and large scale production have stepped back. "To prepare for future disasters we might want to encourage food companies to have five or six food processing plants scattered around the countryside, rather than one giant regional plant," says Jayson Lusk, an agricultural economist at Purdue University (Johnson, 2020, "What does this stress test tell us," para. 2). That sounds hopeful in our current state of disarray and fear. Local farms are pivoting to serve their communities in a time of need. It is also time for consumers who are becoming more aware of where food comes from - and of the true cost of food-to contribute to sustainable, resilient food systems that will continue to support our local farms, long after this pandemic has ended.

\section{References}

Carter, R. (2017). True cost of local food. Montpelier: Vermont Sustainable Jobs Fund, Vermont Farm to Plate. Retrieved from https://www.vtfarmtoplate.com/features/true-cost-of-local-food\#.XpMdTZ17nIU

Chase, L., Becot, F., Estrin, H., Greco, L., Kolodinsky, J., Roche, E., . . Van Soelen Kim, J. (2017, June). Farm Fresh Food Boxes: Expanding rural economies through new markets for farmers and retailers. Paper presented at the joint conference of the Community Development Society and National Association of Community Development Extension Professionals, Big Sky, Montana. Retrieved from http://www.comm-dev.org/images/2017PresentationArchive/Farm Fresh Food Boxes Expanding Rural Economies through New Markets for Farmers and Retailers.pdf

Chase, L., Smith, D., Sitaker, M., Wang, W., Estrin, H., Van Soelen Kim, J., \& Kolodinsky, J. (2019, June). Growing the local food pie: Increasing access and creating new markets for local food. Paper presented at the annual international conference of the National Association of Community Development Extension Professionals, Asheville, North Carolina.

Crampton, L. (2020). Coronavirus has more Americans turning directly to farms for food. Politico. Retrieved from https://www.politico.com/news/2020/03/31/coronavirus-demand-for-local-farms-157538

Harris, J., \& Stephens, L. (2020, April 6). Farm to school efforts during COVID-19 highlight resilient community food systems. National Farm to School Network News. Retrieved from http://www.farmtoschool.org/news-andarticles/farm-to-school-efforts-during-covid-19-highlight-resilient-community-food-systems

Johnson, N. (2020, April 8). Coronavirus myth-busting: The truth about empty shelves and toilet paper shortages. Grist. Retrieved from https://grist.org/food/coronavirus-myth-busting-the-truth-about-empty-shelves-and-toilet-paper-shortages/

Kolodinsky, J. (2017, August). Farm Fresh Food Boxes fill an empty space in the direct to consumer marketplace. Paper presented at the Agricultural \& Applied Economics Association annual meeting, post conference USDA NIFA agricultural economics and rural communities project directors workshop, Chicago.

Kolodinsky, J., Wang, W., Sitaker, M., Chase, L., Estrin, H., Smith, D., \& Van Soelen Kim, J. (2019, June). Developing entrepreneurial partnerships between farmers and retailers: The Farm Fresh Food Box model. Paper presented at the joint conference of the Agriculture, Food and Human Values Society (AFHVS) and the Association for the Study of Food and Society (ASFS), Juneau, Alaska. 
Low, S. A., Adalja, A., Beaulieu, E., Key, N., Martinez, S., Melton, A., . . Jablonski, B. B. R. (2015). Trends in U.S. local and regional food systems (AP-068). Washington, D.C.: U.S. Department of Agriculture, Economic Research Service. Retrieved from https://www.ers.usda.gov/publications/pub-details/?pubid=42807

Northwest Harvest. (2020, April 6). COVID-19 response. Seattle, WA: Northwest Harvest. Retrieved from https://www.northwestharvest.org/covid-19-response

Ricker, H., \& Kardas-Nelson, M. (2020, April 9). Community supported agriculture is surging amid the pandemic. Civil Eats. Retrieved from https://civileats.com/2020/04/09/community-supported-agriculture-is-surging-amid-the-pandemic/

Schmidt, C., Tian, Z., Goetz, S., Bartley, B., Moyer, B., \& Rocker, S. (2020). Farms with direct to consumer sales in the Northeast region and COVID-19: Some early challenges and responses (NERCRD COVID-19 Issues Brief 2020-1). State College: Pennsylvania State University, Northeast Regional Center for Rural Development. https://aese.psu.edu/nercrd/publications/covid-19-issues-briefs/covid-19-and-farms-with-direct-to-consumersales

Schrotenboer, B. (2020, April 4). U.S. agriculture: Can it handle coronavirus, labor shortages and panic buying? USA Today. Retrieved from https://www.usatoday.com/story/money/business/2020/04/04/coronavirus-testsamericas-food-supply-agriculture/5096382002/

Sitaker, M., Becot, F., Chase, L., Estrin, H., Greco, L., Kolodinsky, J., . . Van Soelen Kim, J. (2017, June). Farm Fresh Food Boxes open new markets for farmers and retailers, and benefit rural economies. Paper presented at the joint conference of the Agriculture, Food and Human Values Society (AFHVS) and the Association for the Study of Food and Society (ASFS), Los Angeles.

Sitaker, M., Kolodinsky, J., Estrin, H., Greco, L., Chase, L., Wang, W., Smith, D., \& Van Soelen Kim, J. (2018, June). Consumer response to Farm Fresh Food Boxes, an entrepreneurial partnership between farmers and retailers. Paper presented at the joint conference of the Agriculture, Food and Human Values Society (AFHVS) and the Association for the Study of Food and Society (ASFS), Madison, WI.

Sitaker, M., McGuirt, J., Wang, W., Kolodinsky, J., \& Seguin, R. (2019). Spatial considerations for implementing two direct-to-consumer food models in two states. Sustainability, 11(7), 2081. https://doi.org/10.3390/su11072081

Smith, D. K., Roche, E., Becot, F., Chase, L., Estrin, H. Greco, L., . . Kolodinsky, K. (2017). Farm Fresh Food Boxes: Increasing food access in rural communities through new markets for farmers and retailers. Poster session presented at the Society for Nutrition Education and Behavior Annual Conference, Washington, DC. Retrieved from https://doi.org/10.1016/i.jneb.2017.05.181

Smith, D., Greco, L., Van Soelen Kim, J. E., Sitaker, M., \& Kolodinsky, J. (2018) Farm Fresh Food Box: An innovative new business model in rural communities. Rural Connections, 12(1), 25-28. Retrieved from https://wrdc.usu.edu/files-ou/RC-SPR-SUM-18w.pdf

Smith, D., Wang, W., Chase, L., Estrin, H., \& Van Soelen Kim, J. (2019). Perspectives from the field: Adaptations in CSA models in response to changing times in the U.S. Sustainability, 11(11), 3115. https://doi.org/10.3390/su11113115

U.S. Department of Agriculture. (2017). Census of Agriculture. Washington, DC: USDA, National Agricultural Statistics Services. Retrieved from https://www.nass.usda.gov/Publications/AgCensus/2017/index.php

Van Soelen Kim, J., Chase, L., Estrin, H., Sitaker, M., Smith, D., Wang, W., \& Kolodinsky, J. (2019, February). Farm box pilot project. Paper presented in the Non-Traditional Community Supported Agriculture Models panel at the 2019 Farmers Guild CA Small Farmers Conference, Davis, California.

Vermont Land Trust. (2020). Feeding Vermont during COVID-19: Your guide to farm-fresh local food. Montpelier: Vermont Land Trust. Retrieved from https://www.vlt.org/staygroundedvt/food-guide

Yaffey-Bellany, D., \& Corkery, M. (2020, April 11). Dumped milk, smashed eggs, plowed vegetables: Food waste of the pandemic. The New York Times. Retrieved from https://www.nytimes.com/2020/04/11/business/coronavirus-destroying-food.html 